\title{
Teaching Literature: Musicals' Application in Understanding the Poem for Students in High School
}

\author{
Erisa Kurniati \\ Universitas Batanghari \\ Jambi-Indonesia \\ pures_elf@yahoo.com
}

\begin{abstract}
This article writes about the poem which is one of the literature in which every word contains the meaning of unreal. Every word written in a poem is a beauty that contains a million dependent meanings that read it. But now days, not many can live the poetry so that most of them cannot understand the contents of the poem. Meanwhile, for students, poem is considered something tacky and boring, they mostly like songs and music and short stories or novels, it is really worrying, especially then little by little the poem has begun to be forgotten, at this time the students most assume the poem is tacky And boring because of the difficulty they understand the contents of the poem plus it is indeed a lesson about the poem is very monotonous with the declamation. The problem now is how to attract students attention to this poem lesson so that they can enjoy but more importantly they can more appreciate and understand the contents of the poem in a more interesting way so that when they recite the poem they can take the listener Others dissolve in the rhythm. From some of the difficulties experienced by these students then needed an innovative learning is one of them by using music media with music; learning by using music media is very good to support learning activities to understand poetry. Learning will become more fun and students can better understand poetry better. Students can understand the contents of the poem by living the poem with the help of music media
\end{abstract}

Keywords- Teaching Literature, Musical's Application, and Poem.

\section{INTRODUCTION}

Literature is part of human's life, which is expressed through language in oral or writing form. Literature can be divided into two groups, they are fiction and non-fiction. Non-fiction is the way that is used by author to show and retail about everything that happened actually or really happened based on the fact. Non-fiction consist history, biography and news. Moreover, fiction is the way that is used by an author to show the life based on his point of view. Fiction consists of drama, prose and poem.

Poem is one of literature in which each word contains the meaning of unreal. Every word written in a work of poetry is beauty that contain a million meanings depending on who reads it. However, at present not many can appreciate the poetry, so most of them unable to understand the contents of the poem.

Meanwhile, for the student or students, poem is considered something that is tawdry and dull, they actually liked Most of the songs and music as well as short stories or novels, this is for serious concern, let alone then little by little poetry has begun to be forgotten, according to this writer's observation a few pecans, authors to the conclusion it turns out students consider the poem Most tacky and boring because they are difficult to understand the contents of the poem was added again lesson about the poem that is very monotonous with declamation.

The question now, how does to attract students to the lesson of this poem so that they can enjoy, but more important is that they can more appreciate and understand the contents of the poem in a more interesting so when they recite the poem to come bring Another listener soluble in rhythm. One effective way is to use the music. And as the limit of the problem here is that students can understand the content of poems by living these poems using music media.

Here the writer discuss about how to Musicals' Application in Understanding the Poem for Students in High School.

\section{REVIEW OF LITERATURE}

Definition of Poem

Ethimologycally, the term poem comes from the greek word poites, which means the builder, shaper, maker. In latin from katapoeta, which means build, cause, poem?. In subsequent developments, the meaning of the word is narrowed to the art of literature, whose words are arranged according to specific requirements by using rhythm, rhyme and sometimes a figure of speech.

Base on the oxford dictionary, poem is a piece of writing in which the expression of feelings and ideas is given intensity by particular attention to diction (sometimes involving rhyme), rhythm, and imagery.

Poem is a form of literary work that has art of language which contains aesthetic meaning. It commonly written, read and listened. Kind language in poem more intensely than ordinary language. A poem might be different interpretation of each reader about writer means. To make a perception of a poem, the reader must understand some imagery of poem. It can earn or seen of quality and usually of a word use in poem a word commonly meaning so a reader must be understand and know the word.

Read the poem more than once. A good poem will no more yield its full meaning on single reading that will a Beethoven symphony on a single hearing. Two readings may be necessary simply to let you get your hearings. And if the poem is a work of 
art, it will repay repeated and prolonged examination. One does not listen to a good piece of music once and forget it ; one does not look at a good painting once and throw it away. A poem is not like a newspaper, to be hastily read and cast into the wastebasket. It is to be hung on the wall of one's mind.

1. Denotation and connotation of poem

a. Denotation is dictionary meaning or meaning of word where a word is having a single meaning. Denotation word can stand alone to be understood. It is a word has a suggest beyond express, it has some meaning of one word. Example: "home" has meaning : love, security, comfort, family, etc

b. Connotation is word can't stand alone. It must has context to understand. Connotation to make sentences effectively, but we must think or define twice and couldn't understand directly.

2. Imagery of poem

Imagery is sense of language experience, as a representation of some meaning, so the reader can be imagine of the poetry base on the writer mean. Kind of imagery:
a. Visual imagery. Example: Blue sky, Sunset
b. Auditory imagery. Example: Sound of nature like wind, tress, water
c. Smell imagery. Example: fragrant,
d. Taste imagery. Example: sugar (sweet)
e. Touch imagery. Example: soft, coarse
f. Organic imagery. Example: internal sensation like hunger, thirst, fear.

\section{Figurative Language}

The reason are a number of usage figurative language in poetry: Effectiveness of language, afford imaginative pleasure, bringing additional imagery of speech into verse, more sensuous, adding emotional intensity of speech to other wise merely information and conveying attitudes, and a way to saying much in brief compass
a. Metaphor: is a direct simile of an object. Ex: He is sun.
b. Simily: indirect metaphor. Ex: she likes a beautiful moon.
c. Personification: giving atributes of human being to an animal, object or an idea. Ex: rumput yang bergoyang.
d. Synecdoche: use of part for whole.
e. Metonymy: use of something related for the thing actually.

4. Musical Application in Poem

In 1982 Steven Paul Scher identified three general categories to help us understand the rich connections between music and literature. The category of "music in literature" which includes the literary "imitation...of the acoustic quality of music," adaptations of "larger musical structures and patterns and the application of certain musical techniques and devices" in literary works, and "literary presentation ... of existing or fictitious musical compositions-has been expanded in recent years to encompass a whole manner of ways in which the implications of how music is represented in literature might be understood. Discussions of gender, genre, structure, the nature of creativity, the cultural significance of musical instruments, aesthetics of criticism, and authorial proclivities have all contributed to a rich debate, representative of the "high-quality synergetic interactions" that interdisciplinary studies offer. Scher's two remaining categories, however, were musiccentered: "music and literature" (primarily the setting of text) and "literature in music"broadly related to concepts of musical narrative, where literary paratexts might help us to understand the nature and sequence of specific musical events. Growing numbers of studies in these areas continue to assert interdisciplinary promise, particularly where the nature of the literary text in question suggests a distinctive analytical or interpretative methodology. Given the significant potential of this approach, this special issue, an outgrowth of the 2014 conferences "Words About Music" at Monash University and "Music Literature, Historiography and Aesthetics" at the Institute of Musical Research in London (convened by the Universities of Monash and Leeds), explores further possibilities of how our understanding of specific musical works might be productively revised or enhanced by viewing them through the lens of literary models, works, or allusions.

We define musical understanding as the abilities to engage musical imagination, musical intellect and musical creativity and to be able to apply evidence of such knowings to musical performance. A classic example of musical imagination is found in the very different ways that Franz Süssmayr, Richard Mauder, and Robert Levin finished Mozart's Requiem. We see a glimpse of musical imagination when we listen to Rod Stewart add his distinctive style to great American popular song standards. We hear musical imagination in the raps of hip-hop artists and in the ballads of pop singing stars. Imagining the music that could accompany the flying scene in the movie E. T. or the galactic explorations in the American film classic Star Wars are further examples of musical imagination. Children use their musical imaginations when they create a descant to sing over a given melody or when they work in what Lucy Green $(2002,2008)$ identifies as "friendship groups," creating 
their own versions of their favorite pop recordings. Kids in the garage jamming on their guitars, keyboards, basses, and drums show musical imagination of the highest order.

There are intriguing parallels in the development of contemporary music and of poem. Over the last two decades new music has been liberated and repopularized by its return to tonality and other traditional techniques. Similarly, contemporary poem has been evolving a new freedom that allows it to incorporate sonic possibilities of rhyme and meter, and has thus been returning to its roots as an aural art form. Poem readings, including poem slams related to hip-hop music, have sprouted everywhere.

According to Mr. Dusinberre, playing the Adagio after hearing this poem made the quartet's interpretation "more sensual than elegiac." The reading of the Virgil poem actually establishes the music's link to the subject of sexual abandon and fulfillment, rather than mourning, and also makes a programmatic connection to the wavelike motion of the melody.

\section{FINDING}

According to Poerwodarminto W.J.S, understanding comes from the word "understand" which means to understand right about something. While the understanding of students is the process, actions, ways to understand things and learn is an effort to gain understanding, the essence of learning itself is the search for and finds meaning or understanding. Related to this J. Murshell said: "The content of meaningful lessons for children can be achieved if teaching prioritizes understanding, insight (insight) is not rote and practice.

When we used to ask students what a poem is, we would get answers like "a painting in words," or "a medium for selfexpression," or "a song that rhymes and displays beauty." None of these answers ever really satisfied us, or them, and so for a while we stopped asking the question.

Comparatively, a poem moves a reader, physically or emotionally, very rarely. Other media are much better at bringing us to tears - television, the movies. And if we want the news, we read an article online or glean our Twitter feed. But seriously, isn't a poem a home for deep feelings, stunning images, beautiful lyricism, tender reflections, and/or biting wit? I suppose so. But, again, other arts or technologies seem better at those jobs-novels offer us real or imaginary worlds to explore or escape to, tweets offer us poignant epigrams, painting and design offer us eye candy, and music - well, face it, poetry has never been able to compete with that sublime combo of lyrics, instruments, and melody.

Reading poem well is part attitude and part technique. Curiosity is a useful attitude, especially when it's free of preconceived ideas about what poetry is or should be. Effective technique directs your curiosity into asking questions, drawing you into a conversation with the poem.

Poems speak to us in many ways. Though their forms may not always be direct or narrative, keep in mind that a real person formed the moment of the poem, and it's wise to seek an understanding of that moment. Sometimes the job of the poem is to come closer to saying what cannot be said in other forms of writing, to suggest an experience, idea, or feeling that you can know but not entirely express in any direct or literal way. The techniques of word and line arrangement, sound and rhythm, add to - and in some cases, multiply - the meaning of words to go beyond the literal, giving you an impression of an idea or feeling, an experience that you can't quite put into words but that you know is real.

Steven Paul Scher identified three general categories to help us understand the rich connections between music and literature. The idea of combining poem and music is hardly new. Over the last 10 years, the Irish poet Seamus Heaney has performed his poem accompanied by Liam O'Flynn on the bellows-blown uilleann pipes. In this presentation, heard last year in the same Lincoln Center series, the music simply creates an atmosphere for the spoken word. The pianist Sarah Rothenberg, the artistic director of Da Camera of Houston, has often incorporated poetry readings in her musical presentations, notably in a recital in December at the 92nd Street Y. She arranges the poetry and music to make social and historical connections.

Musical understanding as the abilities to engage musical imagination, musical intellect and musical creativity and to be able to apply evidence of such knowings to musical performance. The challenge was to create a program that would present music and poetry side by side, with cogent but fresh connections that were neither pedantic nor haphazard. First the musicians and the poet agreed on the theme of love, and after research the quartet proposed three pieces of music that had literary backgrounds and dealt with aspects of love.

In this case one way that is used is to use the music media, whereas students read poetry with music media. Music is a collection of tones in which each tune has a beat. The beats here every time it touches the heart rate and met with us, it will cause a sensation that spur to one's emotions, as well as when students read a poem, every time the rhythm of the music blend with the beats then every time she also encouraged her emotions, then indirectly they would more appreciate the poems read. Here is the meeting point where students can understand the contents of the poem were carrying when the student has to appreciate the poem.

The music used in this case should be able to touch directly with a blend of poetry to be read by students. For example, a themed poem beauty should be accompanied by the cheerful music, poetry with the theme of sadness or compassion, or desire should be accompanied by a slow and music. "Auld Lang Syne" is a poem by Robert Burns, The title of this poem is in the language of Scotland, and can be literally translated as 'since a long time ago', 'long ago', or 'the days that have passed'. Although this poem in the language of existing Scodlandia but its version is translated in English. Here are these verses: 


\section{AULD LANG SYNE}

Should old acquaintance be forgot, and never brought to mind?

Should old acquaintance be forgot, and auld Lang syne ?

For auld lang syne, my dear,

For auld lang syne,

We'll take a cup o' kindness yet,

for auld lang syne.

And surely you'll buy your pint cup!

And surely I'll buy mine!

And we'll take a cup o' kindness yet,

for auld lang syne.

We two have run about the hills,

and pulled the daisies fine;

But we've wandered many a weary foot,

since auld lang syne.

We two have paddled in the stream,

from morning sun till dine (dinner time);

But seas between us broad have roared

since auld lang syne.

And there's a hand my trusty friend!

And give us a hand o' thine!

And we'll take a right good-will draught,

for auld lang syne.

\section{LEARNING ACTIVITY:}

\section{WARMING UP:}

- Teacher checks the attendance.

- Teacher asks the students "what is the definition of poem".

- Teacher explains the definition of poem.

- Teacher asks the students to read the poem some times.

- Teacher asks the students to find the difficult.

Teacher prepare the music and let the students to hear music while read the poem by themselves

\section{CORE ACTIVITY:}

Teacher give the students time to read while listen the music, (for the first time, the effective way is after they read the poem.

Teacher ask them to remember parts of the poem while they close their eyes still in listen to the music)

- After that, teacher ask one or more than one of the student to come in front of the class to practice read the poem still accompanied by music, while other students were asked to listen.

- Teacher asks the students to explain what the point is and what the meaning of the poem that has been read is. (Can in personal or in a group).

\section{LAST ACTIVITY:}

- Teacher asks the students to report their work, and discuss it together.

- Teacher give the applause to the students

The source of data is the legend of Malin Kundang who hasbeen posted and who circulated verbally in the community. The data were collected by recording parts of the legend related to Malin Kundang's childhood with his mother interpreted as part of his mother's parenting with content analysis techniques. Interpretation of data is discussed through the literary sociology approach.

\section{DISCUSSION}

According to Poerwodarminto W.J.S, understanding comes from the word "understand" which means to understand right about something. While the understanding of students is the process, actions, ways to understand things and learn is an effort to gain understanding, the essence of learning itself is the search for and finds meaning or understanding. Related to this J. Murshell 
said: "The content of meaningful lessons for children can be achieved if teaching prioritizes understanding, insight (insight) is not rote and practice.

When we used to ask students what a poem is, we would get answers like "a painting in words," or "a medium for selfexpression," or "a song that rhymes and displays beauty." None of these answers ever really satisfied us, or them, and so for a while we stopped asking the question.

Comparatively, a poem moves a reader, physically or emotionally, very rarely. Other media are much better at bringing us to tears - television, the movies. And if we want the news, we read an article online or glean our Twitter feed. But seriously, isn't a poem a home for deep feelings, stunning images, beautiful lyricism, tender reflections, and/or biting wit? I suppose so. But, again, other arts or technologies seem better at those jobs - novels offer us real or imaginary worlds to explore or escape to, tweets offer us poignant epigrams, painting and design offer us eye candy, and music-well, face it, poetry has never been able to compete with that sublime combo of lyrics, instruments, and melody.

Reading poem well is part attitude and part technique. Curiosity is a useful attitude, especially when it's free of preconceived ideas about what poetry is or should be. Effective technique directs your curiosity into asking questions, drawing you into a conversation with the poem.

Poems speak to us in many ways. Though their forms may not always be direct or narrative, keep in mind that a real person formed the moment of the poem, and it's wise to seek an understanding of that moment. Sometimes the job of the poem is to come closer to saying what cannot be said in other forms of writing, to suggest an experience, idea, or feeling that you can know but not entirely express in any direct or literal way. The techniques of word and line arrangement, sound and rhythm, add to-and in some cases, multiply - the meaning of words to go beyond the literal, giving you an impression of an idea or feeling, an experience that you can't quite put into words but that you know is real.

Steven Paul Scher identified three general categories to help us understand the rich connections between music and literature. The idea of combining poem and music is hardly new. Over the last 10 years, the Irish poet Seamus Heaney has performed his poem accompanied by Liam O'Flynn on the bellows-blown uilleann pipes. In this presentation, heard last year in the same Lincoln Center series, the music simply creates an atmosphere for the spoken word. The pianist Sarah Rothenberg, the artistic director of Da Camera of Houston, has often incorporated poetry readings in her musical presentations, notably in a recital in December at the 92nd Street Y. She arranges the poetry and music to make social and historical connections.

Musical understanding as the abilities to engage musical imagination, musical intellect and musical creativity and to be able to apply evidence of such knowings to musical performance. The challenge was to create a program that would present music and poetry side by side, with cogent but fresh connections that were neither pedantic nor haphazard. First the musicians and the poet agreed on the theme of love, and after research the quartet proposed three pieces of music that had literary backgrounds and dealt with aspects of love.

In this case one way that is used is to use the music media, whereas students read poetry with music media. Music is a collection of tones in which each tune has a beat. The beats here every time it touches the heart rate and met with us, it will cause a sensation that spur to one's emotions, as well as when students read a poem, every time the rhythm of the music blend with the beats then every time she also encouraged her emotions, then indirectly they would more appreciate the poems read. Here is the meeting point where students can understand the contents of the poem were carrying when the student has to appreciate the poem.

The music used in this case should be able to touch directly with a blend of poetry to be read by students. For example, a themed poem beauty should be accompanied by the cheerful music, poetry with the theme of sadness or compassion, or desire should be accompanied by a slow and music. "Auld Lang Syne" is a poem by Robert Burns, The title of this poem is in the language of Scotland, and can be literally translated as 'since a long time ago', 'long ago', or 'the days that have passed'. Although this poem in the language of existing Scodlandia but its version is translated in English. Here are these verses:

\section{AULD LANG SYNE}

Should old acquaintance be forgot, and never brought to mind ?

Should old acquaintance be forgot, and auld Lang syne ?

For auld lang syne, my dear,

For auld lang syne,

We'll take a cup o' kindness yet,

for auld lang syne.

And surely you'll buy your pint cup!

And surely I'll buy mine!

And we'll take a cup o' kindness yet, for auld lang syne. 
We two have run about the hills, and pulled the daisies fine;

But we've wandered many a weary foot, since auld lang syne.

We two have paddled in the stream, from morning sun till dine (dinner time); But seas between us broad have roared since auld lang syne.

And there's a hand my trusty friend!

And give us a hand o' thine!

And we'll take a right good-will draught, for auld lang syne.

\section{LEARNING ACTIVITY:}

WARMING UP:

- Teacher checks the attendance.

- Teacher asks the students "what is the definition of poem".

- Teacher explains the definition of poem.

- Teacher asks the students to read the poem some times.

- Teacher asks the students to find the difficult.

- Teacher prepare the music and let the students to hear music while read the poem by themselves

\section{CORE ACTIVITY:}

- Teacher give the students time to read while listen the music, (for the first time, the effective way is after they read the poem.

- Teacher ask them to remember parts of the poem while they close their eyes still in listen to the music)

- After that, teacher ask one or more than one of the student to come in front of the class to practice read the poem still accompanied by music, while other students were asked to listen.

- Teacher asks the students to explain what the point is and what the meaning of the poem that has been read is. (Can in personal or in a group).

\section{LAST ACTIVITY:}

- Teacher asks the students to report their work, and discuss it together.

- Teacher give the applause to the students

Malin Kundang legend has been written by many people, both by using Minangkabau language, Indonesia, and foreign languages. One of them is Malin Kundang written in two languages (Indonesian-English) by M Rantiss published by Bintang Indonesia (2013). Prior to this, Malin Kundang has also been published by Obor Foundation and written by Uddin Syamsudin (1980). Although Malin Kundang is a legend from Minangkabau cultural area in West Sumatra, but has become a popular legend in the archipelago. Therefore, the legend of Malin Kundang is now generally written in Indonesian language.

The legend of Malin Kundang now serves as a bedtime story for children because of its educational factor, i.e. do not imitate Malin Kundang who is lawless to his mother, will later become a stone. It is so rarely books of Malin Kundang legend that tells explicitlyabout period of his childhood when mother cared for, except in passing. Nevertheless, there are some important findings from within oral and written text, such as the following.

(1) There are three versions of Malin Kundang's father, first, dying of illness; second, lost in the storms at sea; and third, never to return from a faraway voyage.

(2) There are two versions of the age of Malin Kundang when his father left. First, when he was still in his mother's arms. Since the loss of his father, Malin Kundang is carried everywhere by his mother so that the people around the year exactly when Malin Kundanglah who was carried by his mother. Secondly, Malin Kundang was in his early years when his father did not come back. Malin goes wherever his mother goes, including going to search for firewood for cooking food. At that time, Malin Kundang is well known as a diligent and obedient child.

(3) According to some versions, Malin Kundang's childhood is a diligent child helping his poor mother. Every day, morning and evening Malin Kundang sells cakes at Sweet Water Beach harbor. It was very helpful to her mother because Malin Kundang was good at trading so her cake was always exhausted, even though she was forced to come home late at dusk. Narrated, other than Malin Kundang famous as a diligent child, he is also known as an honest child. Therefore, the people of the coastal community where he lives put affection on him. 
These three important notes can lead to this research exploring how Malin Kundang relates to his mother who is his true caregiver. Meanwhile, the story of the legend's climax that causes Malin Kundang to be called a rebellious child is when he lies to his beautiful wife, rich, and arrogant, that who embraced her and confessed her mother was not her mother. Again he lied, telling his wife that his mother had died. This climax section is already very popular and this section is also the core of the legend as a lesson.

From some of the findings stated above, it is seen how little-Malin Kundang is cared for lovingly by his mother. It is in accordance with the role of mother (bundo kanduang) in Minangkabau culture, educating children more than a father because his father plays more role in the home of his parents as mamak (Rajo Penghulu, 2004: 71-95). Hard work helps her mother to continue living for daily wood fire, so that Malin Kundang trained physically and mentally from childhood, understanding the meaning of life that life must strive for.

We can state from the findings, Malin Kundang received special attention by the ship's captain for his craft and skill as a porter of loading and unloading. Therefore, Malin was invited to sail by the skipper. This is something that is very exciting because it is secretly Malin Kundang harbor the desire to go sailing to countries far away as his mother's stories. Furthermore, the success of Malin Kundang to get a beautiful wife again nobleman and became the owner of the ship is not told in detail, either through oral stories or through books that have been published.

Malin Kundang success to become the owner of the ship proved by sailing and anchored in his hometown on the coast of Air Manis, Padang. Its success has caused people to wonder about the harbor because they are very familiar with Malin Kundang. This remarkable success made the people immediately tell their mothers that Malin Kundang has returned home with all the luxury. The statement of the villagers is also a tribute to the mother of Malin Kundang who has managed to nurture and educate their children. Unfortunately, Malin Kundang embarrassed to admit his mother who has been old and poor to his wife.

The final part of Malin Kundang legend that causes him to be cursed by his mother to stone is a part of her mother's negligence in educating ethics and morals. Apparently, her mother's parenting is only from the material poverty background not including moral poverty.

\section{CONClusion}

It looks very simple and easy to do, but in reality, there are many teachers who teach students self-taught poem at a very boring, but one thing to remember: music is not just accompaniment or instrument, but music also has a rate that can be integrated on human heartbeat that can affect a person thinking of nature. This is a what we use in providing teaching how students can understand the appreciation of poem through music application, and the result, students understand the poem that given to them easily.

Use of the right music, according to the contents of the poem can make the literature learning, especially for the poem be more live, more fun and creates the new atmosphere in class, so the bore subject like the poem, will never we hear again. It will be very interesting subject for all students.

Base on the explanation and the conclussion above, so the writer suggest: music is not only a media, but music seems like a soul, so in it, we can find many things to make something be easy to understand, in this case the poem is the subject. Teacher can use music application in teaching poem, because many students said that poem is bore, so they can't understand it, but by using music, learning poem can be very enjoy and make students undertsand the poem easily.

\section{References}

Green, L. (2002). How Popular Musicians Learn: A Way Ahead For Music Education. Burlington, VT: Ashgate.

Green, L. (2008). Music, Informal Learning And The School: A New Classroom Pedagogy. Burlington, VT: Ashgate

Julie Thompson Klein and Richard Parncutt, (2010). Art and Music Research. Oxford Handbook of Interdisciplinary, ed. Robert Frodeman, Julie Thompson Klein, and Carl Mitcham Oxford: Oxford University Press.

Lawrence Kramer, Music and Poetry: (1984). The Nineteenth Century and After Berkeley: University of California Press.

Steve Paul Scher, (1982). Literature and Music, in Interrelations of Literature, ed. Jean-Pierre Barricelli and Joseph Gibaldi. New York: Modern Language Association of America.

Steven Connor. (2001). The Decomposing Voice of Postmodern Music, New Literary History 32/3. Summer.

Werner Wolf. (1999). The Musicalization of Fiction: A Study in the Theory and History of Intermediality. Amsterdam: Rodopi. 